\title{
In the Grasshopper Warbler Locustella naevia, males with better nutritional condition at the winter ground arrive earlier than other males at the breeding ground
}

\author{
Hos gräshoppsångare Locustella naevia anlände hanar med bättre fysisk kondition \\ $i$ vinterkvarteret tidigare än andra hanar till häckningsområdet
}

JONAS ENGZELL

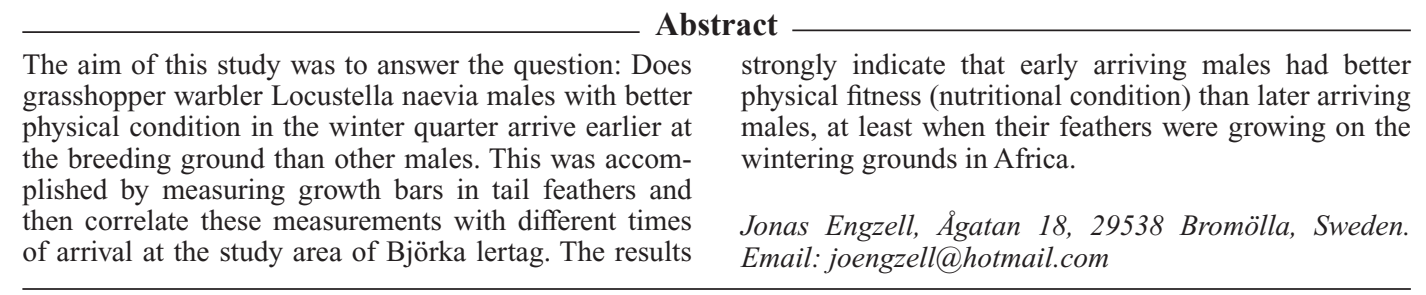

Received 25 September 2017, Accepted 14 October 2017, Editor: Sören Svensson

\section{Background}

Grasshopper warblers Locustella naevia have been monitored in the study area since 1984. As the population over the years increased from one singing male to several, it became apparent that males do not arrive all at once. Some males arrive at the study area in the last days of April or in the first days of May. Other males arrive throughout May. A few turn up as late as in the beginning of June, more or less a month after the first and at a time when the earliest arriving males sing less frequently (indicating that they are breeding).

The aim of the present study was to investigate whether grasshopper warbler males arriving early to the study area were in better physical condition at the time of departure from the winter quarters than males arriving late. As an indicator of condition I used the mean length of growth bars in the tail feathers. One growth bar (one light and one dark bar) corresponds to the growth of the feather during 24 hours.

The validity of using measurements of growth bars as an indicator of condition is summarized by Grubb (2006). The basic assumption is that the greater the average growth bar width, the better the bird's nutritional condition while growing the feather. Grasshopper warblers usually have growth bars in the tail feathers that are visible when holding the bird in the hand, for example during ringing (Figure 1).

Grasshopper warblers nesting in Europe undertake a complete moult in the wintering grounds (Moult -WC) in Africa, before returning to the breeding grounds (Svensson 1992). Kennerley \& Pearson (2010) also states that "the majority of birds moult completely in tropical Africa". Most birds undergo a complete moult in October to January, but in rare cases some birds continue to moult in February and March (Demongin 2016). Thus the growth bars on tail feathers, seen on returning birds in spring, reflect the nutritional condition of the bird during the tail-growth period at the wintering grounds, although not necessarily the condition just prior to departure. Kennerley and Pearson also states "In the nominate race, some adults have a partial post-breeding moult prior to migration, usually confined to the body and head feathers, but sometimes involving the tertials and central tail feathers" Similar facts are stated by Demongin (2016). This makes the central tail feathers less reliable for growth bar measurement in this study, see under Materials and methods. I measured the 


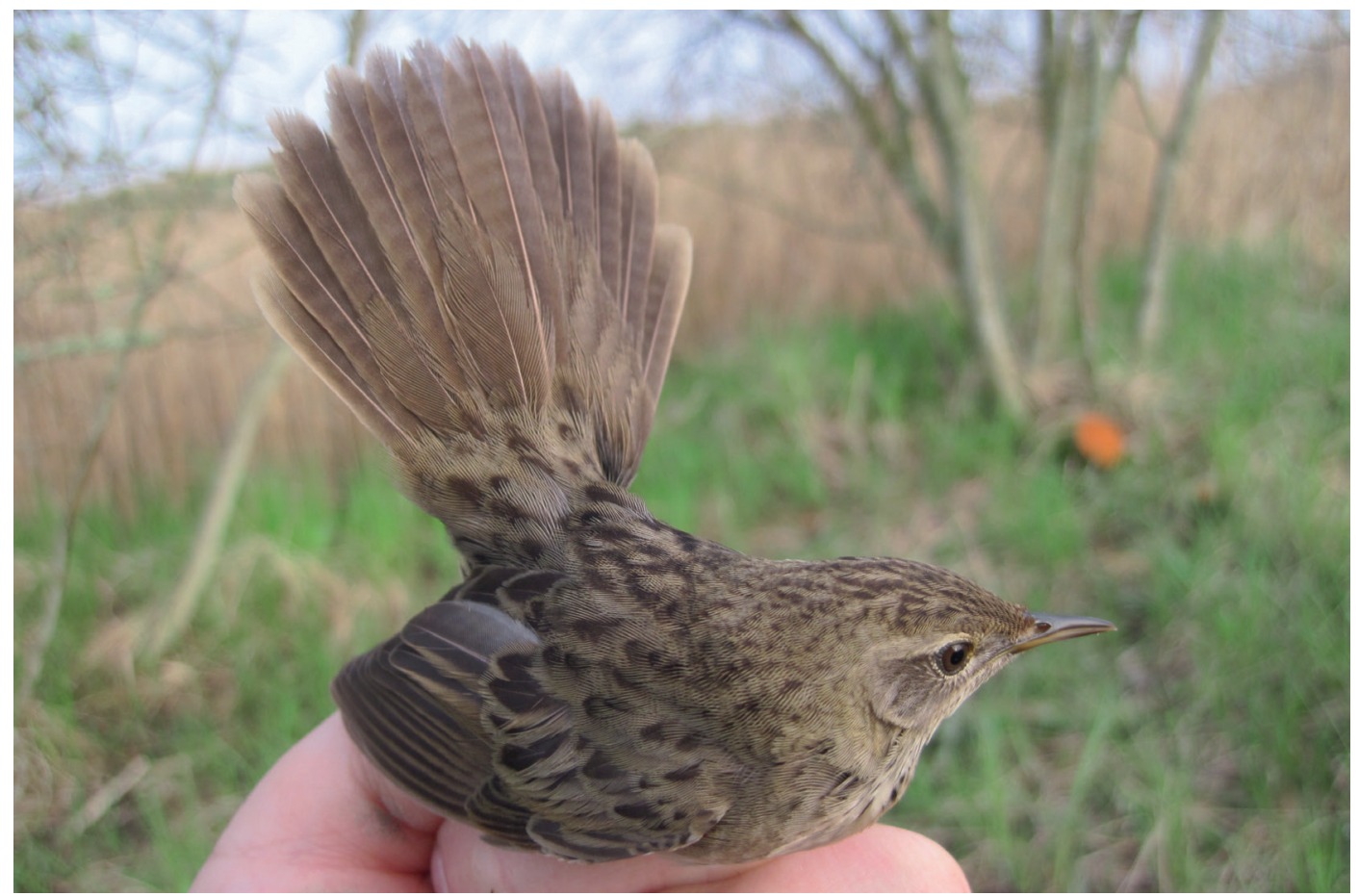

Figure 1. A grasshopper warbler showing the tail with growth bars on the feathers. The tail is moulted during the stay in Africa. The width of one growth bar (one light band grown during night and one dark band during day) represents the growth during 24 hours. Wide growth bars are assumed to be associated with good nutritional status.

En gräshoppsångare demonstrerar stjärten med tillväxtzoner på fjädrarna. Stjärten ruggas under vistelsen i Afrika. Bredden hos en tillväxtzon (ett ljust band under natten och ett mörkt band under dagen) motsvarar tillväxten under 24 timmar. Stor zonbredd anses indikera god näringsstatus.

growth bars on eight grasshopper warblers during 2009 to 2013. This was done as birds were caught in order to answer a different set of questions. The results of these measurements have not been included here, as arrival date was not estimated with the same methodology.

\section{Materials and methods}

\section{Trial year}

The field season of 2014 was used to determine the catching method, method of growth bar analysis, and how to best use the available field days during spring and early summer in order to establish time of arrival with adequate accuracy to answer the question at hand. Five of nine singing males were caught and studied. I found that song playback was necessary and a permit to do this was applied for and granted by Ringmärkningscentralen (Swedish Bird Ringing Center). I also found that the number of growth bars that I could consistently measure with my intended method (Grubb 2006) was 6-7, not 10 , and my method had to be slightly modified to allow for this.

\section{Study area}

The study was carried out in the nature reserve Björka lertag. (Natura 2000 sites: SE0240078 Björka lertag, SE0240134 Vissberga lertag. Object number RegDOS: 2000249. Central coordinates (RT90): X 6554548, Y 1460369). Björka lertag is located in Kumla, Närke, in southern Central Sweden. Once a former clay-pit, it has been turned into a reed- and bush-dominated wetland. For pictures see Engzell (2017).

\section{Establishing time of arrival}

I monitored and ringed singing grasshopper warbler males during the breeding season of 2015, 2016 and 2017, visiting the study area during the same field periods each year, two periods in May and one in early June. In total I made 64 (20 
$+24+20)$ visits to the study area during May and June in 2015-2017 and accumulated $189 \mathrm{~h}$ of observation time.

The date when a bird was first heard singing at a location was used to indicate time of arrival. The true time of arrival could be slightly earlier, if for example the weather affects the willingness to sing or if the bird had arrived in between monitoring visits. Hans Waern has kindly provided me with information of the singing males that he noted during monitoring work between my visits to the study area. That means that males could be placed in three groups with a relatively high confidence: males arriving in week 18-19, 20-21 and 22-24.

The singing positions of males were then used to determine the location of each territory, using standard monitoring technics (Lundström et al. 1984). The males were caught using song playback (song of grasshopper warbler played through a speaker close to the net).

\section{Measuring growth bars}

In the field I used a slightly modified version of a method originally described by Grubb (2006, Appendix 1, s 160-161). After ringing (and taking the standard measurements) the birds tail was placed on top of a paper index card, onto witch I had stapled a piece of thin black paper. Then I marked the growth bars in the outermost tail feather (generally the right) on the paper/index card with a fine pin (insect-mounting pin size 0 ) that was placed in a shaft for ease of handling. The pin was pushed perpendicularly through the feather and the underlying paper at the distal edge of each dark growth band (the edge that is closer to the feathers tip). I also marked the tip of the feather. The method allows for quick and accurate measurement of growth bars without a need for pulling out a tail feather, and with little stress and discomfort for the bird.

I then wrote down the information of the bird individual on the index-card, such as ring number, date and place (territory). The distance between the growth bars was then measured to the nearest 0.01 $\mathrm{mm}$, using magnifiers and a pair of digital calipers. Grubb describes measuring the distance between 10 growth bars and divide by 10 to calculate the mean growth rate. The original method requires you to also mark the base of the (pulled) feather, in order to measure between the 10 growth bars centered around the two-thirds point of the feather. I measured between 7 , or in a few individuals 6 , growth bars, as I found it was often not possible to reliably detect 10 or more growth bars in grasshop- per warbler tail feathers, using my field method. If more than 7 bars were noted, I tried to measure the middle 7 , using the tip of the feather as a reference. Se Grubb (2006) for more details on the original method. My method is therefore slightly less stringent and probably slightly less accurate. But my method does not require pulling out a feather, for which I do not have a permit (required in Sweden).

\section{Analysis}

The results have been analyzed using a one way ANOVA, computed using the Analysis ToolPak in Microsoft Excel (2013). No Tukey Test have been computed, since there was not an equal number of sampling units in all samples. The null hypothesis was that the mean growth rate did not differ between the tree groups (males arriving in week $18-19,20-21$ or $22-24)$.

\section{Results}

In 2015 I caught 9 individuals, 4 arriving in week 18-19, 3 arriving in week $20-21$ and 2 arriving in week 22-24 (4, 3, 2). In 2016 I caught 6 individuals $(3,3,0)$ and in 2017 I caught 10 individuals (1, $6,3)$.

The results on a population level is presented in Figure 2 and in Table 1 and 2.

The difference in mean growth rate (growth per day) of the tail feathers between the three samples, $n=8,12$ and 5, is statistically significant since $\mathrm{F}>\mathrm{Fcrit}(\mathrm{F}=19,02008>3,443357)$. The result is significant at the $1 \%$ significance level. The null hypothesis is rejected. I conclude that there is strong evidence that the mean growth rate in the tree groups differ.

In Table 3 the results are presented on an individual level. Arrival and mean growth rate of tail feathers of individuals that have been captured (year 1) and recaptured one year later (year 2) are shown. Males ringed/caught in 2014-2017 are included. (Two birds caught in 2014 and re-caught in 2015 are included here, as their time of arrival and tail growth could be determined using the same method as in 2015.)

\section{Discussion}

The results strongly indicate that the earliest arriving males had a better nutritional condition than later arriving males when their feathers grew at the wintering grounds in Africa. The males that arrived late had been, in general, in less good condition at 


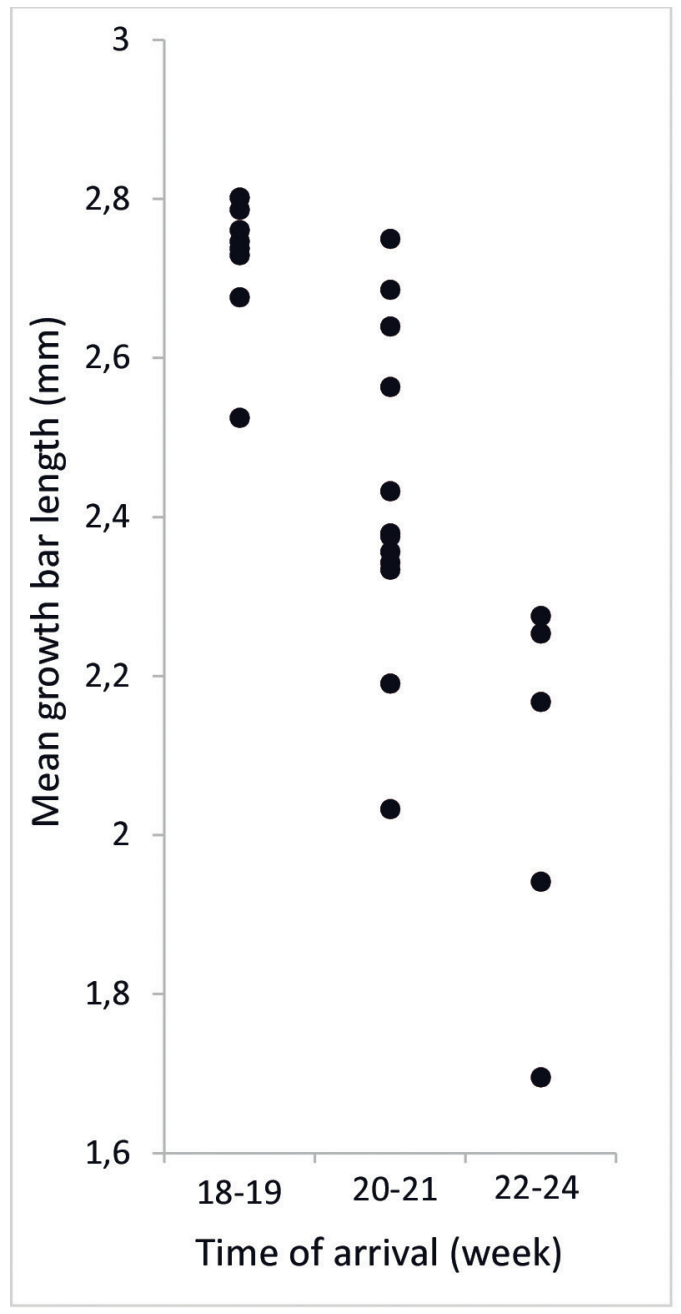

Figure 2. Mean tail growth rate for Grashopper Warbler males arriving in week 18-19, 20-21 and 22-24 during 2015-2017. Medelvärdet av stjärttillväxten för hanar av gräshoppsångare som ankom under vecka 18-19, 20-21 och 22-24 under år 2015-2017.

the wintering grounds than the males that arrived before them. The data also suggests that there is less variance in the mean tail growth in the group of early arriving males and that this variance increases in the groups arriving later.

Even if too few individuals have been recaptured for statistical analysis to be meaningful, the result on an individual level seems to support the findings on a population level. Individual males such as CK16785 and CK16786, that had a markedly higher mean growth rate year $2(+0,345-0,621 \mathrm{~mm})$, also arrived earlier that year. Individuals with only a slight difference in mean growth rate $(+/-0,014-$ $0,054 \mathrm{~mm}$ ) did not change their time of arrival. At least not as much as to be detectable in this study.

It seems that males with better nutritional condition on the wintering grounds arrive earliest to Björka lertag and that they therefore (theoretically) can claim the best territories there. On the other hand, males arriving early to Björka lertag risk periods of cold weather and a lack of food to a higher degree than later arriving individuals. Probably these are two opposing evolutionary forces working against each other.

\section{Acknowledgements}

I would like to thank: Hans Waern for shared information on arriving males, Sofia Engzell for comments on the manuscript, Rune Engzell, Margareta Engzell and Helmi Dam for logistic support and Katrin Johansson for help with Microsoft Excel.

\section{References}

Engzell, J. 2017. Are there more ground-dwelling invertebrates inside than outside Grashopper Warbler Locustella naevia territories? Ornis Svecica 27: 10-12.

Demongin L. 2016. Identification Guide to Birds in the Hand. Beauregard-Vendon. ISBN 978-2-9555019-0-0.

Grubb, T.C., Jr. 2006. Ptilochronology - Feather Time and the Biology of Birds. Oxford University Press, ISBN 0-19929550-6.

Kennerley, P. \& Pearson, D. 2010. Reed and Bush Warblers. Christopher Helm, London. ISBN 978-0-7136-6022-7.

Lundström, S. et al. 1984. BIN, Biologiska Inventeringsnormer Fåglar. Statens Naturvårdsverk - Råd och riktlinjer, RR 1978:1, ISBN 91-38-04079-4.

Svensson, L. 1992. Identification Guide to European passerines. Pp. 160-161. ISBN 91-630-1118-2.

\section{Sammanfattning}

I Björka lertag, Närke, anländer gräshoppsångarhanar under en relativt lång period. De tidigaste anländer under de sista dagarna $\mathrm{i}$ april eller de första dagarna i maj. Därefter anländer hanar under maj fram till i början av juni - när de tidigast anländande hanarna inte längre sjunger lika regelbundet (vilket indikerar påbörjad häckning).

Frågan som jag har försökt besvara är om tidigt anländande hanar är i bättre kondition än sent anländande hanar. Detta undersöktes genom att mäta den genomsnittliga tillväxten på stjärtpennorna och korrelera detta mot ankomstdatum.

Under 2015-2017 inventerades/revirkarterades sjungande hanar. Första gången de hördes på en plats räknades som ankomstdatum. Hanarna fån- 
Table 1. Summary from the ANOVA calculation of tail growth rate and arrival of grasshopper warblers. Sammanfattning från ANOVA beräkningen av stjärttillväxt och ankomsttid hos gräshoppsångare.

\begin{tabular}{lccll}
\hline Groups (Arrival) & Numbers & Sum & Mean value & Variance \\
\hline Sample 1 (Week 18-19) & 8 & 21,767 & 2,720875 & 0,007702125 \\
Sample 2 (Week 20-21) & 12 & 29,087 & 2,42391667 & 0,042892447 \\
Sample 3 (Week 22-24) & 5 & 2,0672 & 2,0672 & 0,0605292 \\
\hline
\end{tabular}

Table 2. One Way ANOVA for tail growth rate and week of arrival in grasshopper warbler. Envägs ANOVA för stjärttillväxt och ankomsttid hos gräshoppsångare.

\begin{tabular}{lllllll}
\hline Source of variation & $\mathrm{KvS}$ & $\mathrm{fg}$ & $\mathrm{MKv}$ & $\mathrm{F}$ & $\mathrm{p}$-value & F-crit \\
\hline Between samples & 1,327685 & 2 & 0,6638427 & 19,0200772 & $1,6 \mathrm{E}-05$ & 3,443357 \\
Within samples & 0767849 & & 0,03490221 & & & \\
Total & 2,095534 & & & & & \\
\hline
\end{tabular}

Table 3. Change in mean tail growth rate of the outer tail feather between two years for five individual males, and their different times of arrival.

Medelförändring $i$ tillväxthastighet hos den yttre stjärtpennan mellan två år för fem hanar och deras olika ankomsttider.

\begin{tabular}{llllll}
\hline $\begin{array}{l}\text { Ring } \\
\text { number }\end{array}$ & $\begin{array}{l}\text { Tail growth } \\
\text { year 1 }(\mathrm{mm})\end{array}$ & $\begin{array}{l}\text { Tail growth } \\
\text { year 2 }(\mathrm{mm})\end{array}$ & $\begin{array}{l}\text { Change } \\
(\mathrm{mm})\end{array}$ & $\begin{array}{l}\text { Arrival } \\
\text { year 1 }\end{array}$ & $\begin{array}{l}\text { Arrival } \\
\text { year 2 }\end{array}$ \\
\hline CK16869 & 2,787 & 2,802 & $+0,015$ & W. 18-19 & W. 18-19 \\
CK16826 & 2,761 & 2,747 & $-0,014$ & W. 18-19 & W. 18-19 \\
CK16875 & 2,334 & 2,388 & $-0,054$ & W. 20-21 & W. 20-21 \\
CK16785 & 2,109 & 2,730 & $+0,621$ & W. 20-21 & W. 18-19 \\
CK16786 & 2,295 & 2,640 & $+0,345$ & W. 22-24 & W. 20-21 \\
\hline
\end{tabular}

gades sedan för ringmärkning. I samband med det mättes stjärttillväxten genom att avståndet mellan de tillväxtzoner man kan se i stjärtfjädern mättes. Genom att mäta avståndet mellan 7 , eller i vissa fall 6 , tillväxtzoner i den yttre stjärtfjädern, erhölls ett medelvärde. Detta medelvärde kunde sedan korreleras mot ankomstdatum, där hanarna delades in $\mathrm{i}$ tre grupper. En grupp som anlände vecka 18-19, en grupp som anlände v. 20-21 och en sista grupp som anlände v. 22-24.

Beräkningar visade sedan att det fanns en statistiskt säkerställd skillnad i stjärttillväxten mellan dessa tre grupper. Stjärttillväxten speglar fågelns "näringsstatus" när fjädern växer ut. Då gräshoppsångare byter sina fjädrar på övervintringsplatsen $\mathrm{i}$ Afrika, slår jag fast att resultaten från denna studie starkt indikerar att tidigt anländande hanar är i bättre kondition på övervintringsområdet i Afrika än sent anländande hanar. Resultat får även stöd $\mathrm{i}$ att individuella hanar, som fångats två år efter varandra och där den genomsnittliga stjärttillväxten ökat markant det andra året, även anlänt tidigare år två. Hanar med måttlig förändring i tillväxten har däremot inte nämnvärt ändrat ankomsttid till studieområdet. 